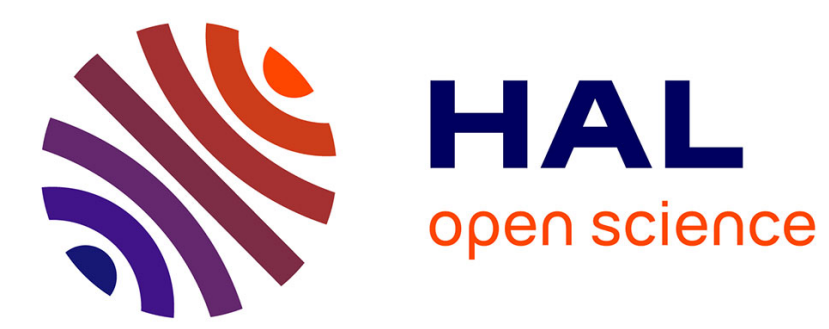

\title{
ATI AND FREE-FREE TRANSITIONS IN A COULOMB FIELD
}

\author{
E. Karule
}

\section{To cite this version:}

E. Karule. ATI AND FREE-FREE TRANSITIONS IN A COULOMB FIELD. Journal de Physique IV Proceedings, 1991, 01 (C7), pp.C7-788-C7-788. 10.1051/jp4:19917215 . jpa-00250924

\section{HAL Id: jpa-00250924 https://hal.science/jpa-00250924}

Submitted on 1 Jan 1991

HAL is a multi-disciplinary open access archive for the deposit and dissemination of scientific research documents, whether they are published or not. The documents may come from teaching and research institutions in France or abroad, or from public or private research centers.
L'archive ouverte pluridisciplinaire HAL, est destinée au dépôt et à la diffusion de documents scientifiques de niveau recherche, publiés ou non, émanant des établissements d'enseignement et de recherche français ou étrangers, des laboratoires publics ou privés. 


\section{ATI AND FREE-FREE TRANSITIONS IN A COULOMB FIELD}

\section{E. KARULE}

Institute of Physics of Latvian Academy of Sciences, Salaspils-1, Latvia, Riga 229021, USSR

In plasma atoms and ions may be considered as free particies. Multiphoton ionization is one of the processes due to which laser energy is transferred to plasma. In strong laser fields except multiphoton ionization by minimum energeticaliy necessary number of photons (MPI) the so called above threshold ionization (ATI) with excess number of photons is possible.

In our paper multiphoton ionisation, ATI and free-free transitions in a Coulomb field are investigated theoretically using quantum mechanical perturbation theory methods.

Modified Coulomb Green function CCGF Sturmian expansion are presented: It consists of two parts. One part coincides with CGF representation by Whittakers functions but without the statement that one of the radial variables must be lesser or greater than another. The second part is expressed as a double sum.

Two and three-photon above threshold ionization (ATI) are calculated $(N=2, S=1: N=3, S=2)$ for atomic hydrogen in the ground state using modified CGF.

The cases in which the modified CGF may be used to evaluate two-photon free-free transition matrix elements are discussed. The dependence of two-photon free-free transition matrix elements on electron energy and light frequency are presented.

Modified CGF may be used also in multiphoton ATI ionization when the total number of photons are greater than three. By use of quantum defect theory modified CGF can be applied to alkali atoms. 